\title{
Technological Advances in Huanglongbing (HLB) or Citrus Greening Disease Management
}

\author{
Krishna Prasad Paudyal \\ Communication, Publication, Documentation Division, Lalitpur \\ Email:kppaudyal@yahoo.com
}

Received April 2015; Revised June 2015; Accepted July 2015

Scientific Editor: C. Regmi, BK Joshi

Copyright (C) 2015 NARC. Permits unrestricted use, distribution, and reproduction in any medium, provided the original work is properly cited

\begin{abstract}
Huanglongbing (HLB), previously citrus greening disease, is the most destructive of citrus species causing major threat to the world citrus industry. The disease was reported from China in 1919 and now known to occur in more than 40 different countries of Asia, Africa, South and North America. Three species of gram negative bacterium namely Candidatus Liberibacter asiaticus, Candidatus Liberibacter africanus and Candidatus Liberibacter americanus are the casual organisms of HLB, respectively prevailing in the continent of Asia, Africa and South America. It is one of the most extensively researched subjects in citriculture world. HLB was detected in 2004 and 2005, respectively in San Paulo of Brazil and Florida of USA: the two leading citrus production hub of the world causing huge economic loss within 5 years of first detection. Since then research on HLB detection and management was further accelerated in American continents. This paper presents the scientific advancement made on detection, spread, economic losses caused by HLB in different parts of the world and controlling management strategies. Remarkable achievements have been made on HLB detection techniques including iodine test, qPCR and more recently in spectroscopy. While efforts are being made to develop resistance varieties using conventional and biotechnological tools management strategy which includes reduction of inoculums source, vector control and replant with disease-free planting materials still remains major option for HLB control. Citrus intercropping with guava have shown promising results for vector reduction.
\end{abstract}

Key words: Citrus, citrus greening, huanglongbing, liberibacter, management

\section{सारांश}

ह्वाङ्लोड्गब्ड़ (यच यल बि) रोग, सुन्तलाजात खेतीका लागि संसारभर मुख्य चुनौती हुदै आएको छ। यसको पुरानो नाम सिट्रस ग्रिनिड रोग हो । सन् १९१९ मा सर्वप्रथम चीनबाट यस रोगको बारेमा विवरण प्रकाशित भएको थियो। हाल यो रोग एसिया, अफ्रिका, उत्तर तथा दक्षिण अमेरिकाका ४० भन्दा धेरै देशहरुमा फैलिसकेको छु। एसिया, अफ्रिका र दक्षिण अमेरिकामा कमस: क्यान्डिडाटस लिवेरिब्याक्टर एसियाटिकस, क्यान्डिडाटस लिवेरिब्याक्टर अफ्रिकानस र क्यान्डिडाटस लिवेरिब्याक्टर अमेरिकानस प्रजातिका ब्याक्टेरियाले यो रोग लगाउछ। ठलो आर्थिक नोक्सानी गर्ने भएकाले सुन्तलाजात फलफुल बालीमा यस रोगको बारेमा अत्यन्तै धेरै अनुसन्धानहरु भएका छन् । यस बालीको ब्यवसायिक उत्पादनका लागि संसारमा नै ठला मानिएका ब्राजिलको सनपाउलो र संयुक्त राज्य अमेरिकाको फ्लोरिडा राज्यमा कमस: सन् २००४ र २००४ मा यो रोग देखिएको $y$ वर्ष भित्रमा धेरै आर्थिक क्षति पुच्याए पछि, यस रोगको अनुसन्धानले अमेरिकी महादेशमा अभै ब्यापकता पायो। यस लेखमा यच यल बि रोगको पहिचान, फैलावट, यसले पुच्याउने आर्थिक क्षती र यो रोगको ब्यवस्थापनका विषयमा गरिएका बैज्ञानिक प्रगतिका बारेमा चर्चा गरिएको छ। रोग पहिचानको लागि आयोडिन टेस्ट र पिसिआरको प्रयोग हुदै आएकोमा हालका वर्षहरुमा सजिलो र सस्तो स्पेक्ट्रोस्कोपी प्रविधिको प्रयोगमा पनि अनुसन्धान केन्द्रित भएका छन् । रोग नियन्त्रणका लागि परम्परागत र जैविक प्रविधिको प्रयोगबाट रोगअवरोधक जातको विकासका प्रयास भएपनि आशा अनुरुपको प्रतिफल प्राप्त नभएको परिप्रेक्षमा हालसम्म पनि रोगी बोटहरु हटाउने, रोगको कारक ब्यक्टेरियाको संवाहक सिट्रस सिल्ला किरा नियन्त्रण गर्ने र निरोगी कलमी विरुवाको प्रयोग गरी पुनर्रोपण गर्नु नै यस रोगको ब्यवस्थापनको विधि रहेको छ। यच एल बी रोगका सम्बाहक नियन्त्रणको लागि सुन्तला र अम्बा संगसंगै लगाउदा केहि आशाजनक नतिजा प्राप्त भएको छ।

\section{INTRODUCTION}

Globally, citrus fruit represents one of the most important commodities with respect to production and trade. In production volume, it occupies second position after banana and plantain (Statista 2012) and ranks top position in international trade in terms of value (UNCTAD 2011). In Nepal, citrus especially mandarin, sweet orange and lime, are among the commodities having high potential for commercial production. The mid-hill region of Nepal have favorable conditions for commercial production of citrus because of agroclimatic suitability, access to domestic and regional markets and past experiences of farmers on citrus farming. As a result of these reasons along with government priority for its commercialization the area under citrus cultivation and its total production have increased substantially over the years. In the year 2003/04, 148,010 mt of fresh citrus fruit was produced in Nepal from 24,799 ha area. The total area under citrus cultivation has increased to 36,975 ha and total production to 216,188 mt in 2012. However, productivity of citrus decreased to $9.14 \mathrm{mt} / \mathrm{ha}$ in 2012 compared to $10.62 \mathrm{mt} / \mathrm{ha}$ in 2003 ((MoAD 2013).

Among many biotic factors contributing to low productivity and threat to citrus industry huanglongbing or greening disease, hereafter HLB has been considered the number one in Nepal (Regmi and Yadav 2007, Roistacher 1996) and the world (Bové 2006, 2014). HLB was first reported from southern China in 1919 and is now known to occur in more than 40 different Asian, African, Oceanian, South and North American countries (Bove 2006).

In Nepal, the disease was first reported from Pokhara in 1968 (Thrower 1968) as the main cause of citrus decline in the country (Roistacher 1996, Regmi and Yadav 2007). The disease is caused by a phloem-restricted, non cultured, Gram-negative bacterium transmitted by citrus psyllid insect vector; non-curable once trees are affected. Since HLB is very destructive disease and slowly invading new citrus growing areas represent a major threat to the world citrus industry including Nepal. 
Mandarin (Suntala), sweet orange (Junar) and acid lime (Kagati) are the major commercial citrus species grown in Nepal (MoAD 2013). Since all citrus species are infected with HLB in varying degree and the disease is already spread several parts of the country (Bove 2006) understanding the complex nature of the disease and its management approaches is very vital to save the citrus industry of the country. In this context recent updates on technological information on detection and control management of HLB would be worth to be elucidated. Therefore, this paper presents a review on history, geographical distribution, detection and management of HLB.

\section{CAUSAL ORGANISM}

Citrus greening disease or HLB was first reported from China in 1919 by Reinking while evaluating diseases of economic plants in southern China and used English term "yellow shoot" of citrusin the report, however, for a long period it (at that time the name "HLB" was not used) was thought to be present in China (Bove 2006). At that time it was believed that the HLB was caused by abiotic factors like Zn deficiency/toxicity and poor drainage system (Oberholzer et al 1965). By 1967, it became established that greening was graft and insect transmissible with conclusion caused by virus (Bove 2006). In 1967, mycoplasm like organisms (MLOs) were believed to be associated with plant diseases mostly with "yellow" symptoms resembling with greening symptoms. On close examination, these organisms were seen to have bacterial cell wall in addition to cytoplasmic membrane, suggesting that they were gram negative true bacteria (Garnier and Bove 1977). Thus, it was concluded that the HLB agent was gram negative bacterium. Later on it was confirmed by Electron Microscopy that South African "greening", Indian "dieback", Taiwan "likubin" and Philippines "mottle leaf" all were caused by HLB bacterium (Bove 2006).

Using universal primers, the 16s ribosomal DNA of two strains of the bacterium obtained by Polimerage Chain Reaction and comparisons with gene sequences showed the HLB organism belonged to the subdivision of the class Protobacteria, but were distinct from other members. The bacterium from Asia named Candidatus Liberibacter asiaticus (Las), and the African Ca. L. africanus (Laf) (Garnier et al 2000). Ca. L. americanus (Lam) is the new species identified in 2005 causing HLB in Brazil (Teixeira et al 2005).

The three species of HLB causing bacteria differ in their pathogenicity due to combination of environmental conditions and insect vectors (Jagoueix et al 1996). The African strain of HLB is heat sensitive and does not cause symptoms at temperatures greater than 25$30^{\circ} \mathrm{C}$. The Asian strain, primarily distributed in Asia, is heat tolerant and able to cause symptoms at temperatures greater than $30^{\circ} \mathrm{C}$. The American strain, which is reported from Brazil and Mexico, appears to have heat tolerance similar to that of the African strain (NAPPO 2012).

\section{HISTORY \\ Origin of HLB}

Although HLB was first reported from China where many citrus species were originated most scientists believe that citrus species are not the original host of the HLB organism (Beattie et al., 2005, Bove, 2006 and Graca, 2011). There are different opinions among researchers about the origin of HLB. One of the hypothesis is that Asian HLB originated in citrus in India from unidentified native rutaceae and may have moved to other Asian countries through planting materials and citrus psyllids including China and other southeast Asian countries (Graca 2011).

Beattie et al. (2005) have proposed another hypothesis that the disease may actually originated in Africa, possibly in an asymptomatic host such as Verpris lanceolata; then transmitted to citrus by insect in European settlement on the east coast of Africa and then taken to the Indian subcontinent in infected plants or budwood 300 to 500 years ago, and then into China later. It has been recently suggested that the liberibacters have Gondwanan origins (Beattie et al 2005, Bove 2006).

At present HLB has spread to most of the citrus growing countries of the word. Only the areas free from HLB as well as of the psyllid vectors of the disease are Mediterranean basin, most of Western Asia (Near and Middle East), Australia, and North- and South-Pacific islands are still free of HLB (Bove 2006). Detail updated information of the disease distribution can be obtained from the website: http://www.cabi.org/isc/ datasheet/16567.

\section{China}

Reinking (1919) used English word “yellow shoot” of citrus, a disease thought to be of little importance in those days. Later surveys showed that by 1936 the disease had spread to become a serious problem. The most extensive work on HLB in southern China was conducted from 1941 to 1955 by Lin Kung Hsiang (Bove 2006). From the discussions with the farmers of the Chaozhou county in Guangdong province, it was learned that HLB actually had been there since the 1870s. Based on this Lin postulated that HLB originated from Guangdong Province, China. He conducted several exploration in China and disclosed that farmers of Chaozhou district had given the name "huang long bing" to the disease, where "huang” means yellow, 'long' meant to 'dragon' and "bing" stands for disease. Hence, the disease was called "yellow dragon disease". The most outstanding result obtained by Lin was the demonstration, by precise experimental work, that HLB is a graft-transmissible, infectious disease, and should neither be attributed to physiological disorders such as mineral deficiencies or water logging, nor to soil-borne diseases such as nematode infestation or Fusarium infection (Bove 2006). For these reasons, the International Organization of Citrus Virologists (IOCV) accepted the official name of the disease be huanglongbing (HLB) in 1995 at the $13^{\text {th }}$ conference of the Organization in Fuzhou (Fujian, China).

\section{Africa}

A disease similar to HLB, was observed in South Africa in 1928 under the name "greening”. However, the true nature of the disease was not immediately recognized, and in the first description of "greening" in 1937, the problem was still assumed to be mineral toxicity (Oberholzer et al 1965). Through a collaborative research by A.P.D. McClean (phytopathologist) and P.C.J. Oberholzer (horticulturist) 
demonstrated that greening was transmissible by graft inoculation as well as by the African citrus psylla, T. erytreae. The infectious nature of "greening" was thus established. The name "greening" was adopted by the scientific literature until "huanglongbing" was given as the official name in 1995, probably because of the proximity of western scientists to South Africa (Gottwals et al 2007).

\section{Philippines}

The disease became a serious problem in the late 1950s was described in 1921 with the name - "mottle leaf" and thought to be related to zinc deficiency, because the symptoms of "mottle leaf" were very similar to those of HLB in China and Taiwan, and "greening" in South Africa (Salibe and Cortez 1968). Being graft-transmissible, HLB has also insect vectors: the African citrus psyllid, Trioza erytreae, reported as the vector in South Africa in 1965 and the Asian citrus psyllid, Diaphorina citri, identified as the vector in Asia (India and Philippines) in 1967 (Bové 2006).

\section{Other South-east Asian Countries}

In Indonesia, HLB became a major problem identified first time in the name of "Vein phloem degeneration" or "phloem necrosis" in 1940s (Tirtawidjaja et al 1965). HLB first appeared in Thailand in the 1960s and was so severe that the length of time between the onset of the disease and debilitation of the entire tree was only about two years (Schwarz et al 1973). HLB disease, locally called "Likubin" was first identified in Taiwan in about 1930, but not considered as serious problem until 1957 (Gottwald 2007). The HLB inoculums was assumed to be brought into Taiwan from southern China through some infected citrus scions or seedlings and thought to be associated with poor soil conditions such as deficiency in essential nutrients or poor drainage (Su 2008). Other south Asian countries where HLB has also been detected by DNA hybridization and/or PCR include Myanmar, Malaysia, Cambodia, Laos and Vietnam (Bove 2006)

\section{India}

Citrus in India has been known to suffer seriously from certain disorders resulting in low production, twig dieback, slow death and even sudden wilting attributed to "dieback", a disease that was first observed in the $18^{\text {th }}$ Century in central India (Bove 2006). Proof for the presence of HLB in India was eventually obtained at the virus Research Center at Poona by Capoor and co-workers, when they succeeded in transmitting the HLB pathogen by the Asian psylla, D. citri by demonstrating that trees with dieback symptoms invariably proved positive for HLB (Capoor et al 1967). Thereafter, it was reported from different citrus growing regions of India and was considered to be principal cause of citrus dieback disease (Das 2008). From several surveys conducted from 2007 to 2012 along with molecular test (real-time PCR) in 16 states of India confirmed its distribution in all studied states (except Arunachal Pradesh): Andhra Pradesh, Assam, Karnataka, Madhya Pradesh, Maharashtra, Manipur, Meghalaya, Mizoram, Nagaland, Punjab, Rajasthan, Sikkim, Tamil Nadu, Tripura and West Bengal (Das et al 2014)

\section{Pakistan}

Several surveys conducted during 1991 showed that citrus greening disease (CGD) is one of the most important and severe disease in Punjab and North West Frontier Province having an incidence rate of 22\% in Kinnow, 25-40\% in sweet orange, 15\% in grapefruit, 10\% in sweet lime, and $2 \%$ in lemon (Batool et al 2007).

\section{Nepal}

Citrus decline was reported for the first time in Pokhara valley by Thrower (1968). Based on visual observation, Knorr et al (1970) suspected that the decline was caused by greening disease entered with the planting materials introduced to Horticulture Research Station, Pokhara from Saharanpur, India. About 55\% of citrus trees in Pokhara valley and 100\% in Horticulture Research Station were symptomatic to HLB in 1980s (Regmi 1982). Later more surveys and studies were carried out in other parts of the country to explore the distribution of greening disease and its vector (Regmi and Lama 1988, Regmi 1994, Regmi et al 1996). More recent PCR test showed that HLB is widespread in many citrus pockets of Kaski, Syanja, Tanahu, Lamjung and Dhading districts (Bove 2006, Regmi and Yadav 2007, Regmi et al 2010).

\section{America}

Brazil has been the first American countries to report HLB, in March 2004 San Paulo State eliminated about 6 million infected trees by 2008, (Lopes et al 2011). The major HLB agent was the new liberibacter species Ca. L. americanus, present in $92 \%$ of the trees (Bove 2006). From 2005 on, the rest of America and the Caribbean islands started to be invaded by Las and D. citri: first Florida in 2005, then Cuba in 2006, followed by Mexico, Belize, Central America in 2009, Argentina, California, Guadeloupe andTexas (Bove 2014).

\section{DETECTION OF HUANGLONGBING}

\section{Visual Symptoms}

Citrus trees can be suspected to be affected with HLB by visual symptoms appeared on leaves and fruits (Bove 2006). A tree infected with HLB in the field usually develops one or more yellow shoots with other parts of the tree healthy or symptomless. The affected leaves develop a pattern of yellow and green areas lacking clear limits between the colors, giving a "blotchy mottle" appearance. This is the most characteristics foliar symptom and the patterns are asymmetrical on the two halves of the leaf (Bove 2006). Leaves can also become thicker, with veins enlarged and corky in appearance. 
In later stages, Zn deficiency-like symptoms can be seen followed by leaf drop and twig dieback (Gottwald et al 2007). Symptomatic fruit are small, lopsided and as they mature and ripen the stylar end remains green, hence named as "greening" (Bove 2006). When cut in half, small, dark aborted seed can be observed and vascular bundles in the fruit axis are discolored. Fruit, especially sweet oranges, can also have mottle appearance and if the peel is pressed with finger, a silvering of the depressed area will result (Bove 2006). Visual symptoms of HLB noticed on leaves and fruits are varied and can be resemble other disorders like micronutrient deficiencies, such as zinc, manganese and iron (Etxeberria 2007).

Johnson et al (2014) found that greening causes a loss of 30-50\% of trees' fibrous roots before symptoms are visible above ground. HLB bacteria enter trees through leaves but the disease attacks roots long before the leaves show signs of damage. Once bacteria enters through psyllid sucks into leaves, the bacteria travel quickly to the roots, where they replicate, damage the root system and spread to the rest of the host tree's canopy (Johnson et al 2014).

\section{Molecular Diagnosis}

For the diagnosis of HLB, two molecular techniques have been used: conventional Polymerase Chain Reaction (PCR) and real time PCR (RT-PCR), also known as quantitative PCR (qPCR) that are based on the use of PCR primers that amplify DNA sequences of the Liberibacters associated with HLB (Bove 2006). Conventional PCR methods use specific primers that amplify the sequences of the rDNA 16s genes and primers based on the proteinaceous genes (operon-B) (Jagoueix et al 1996, Tian et al 1996, Hocquellet et al 1999, Teixeira et al 2005). The low concentration and irregular distribution of the pathogen in host plants, along with the inhibitors of PCR present in citrus extracts made the detection of the pathogen difficult. Although conventional PCR and qPCR are accepted techniques for the confirmation of trees symptomatic for HLB in Brazil and the United States, qPCR is considered much more sensitive and robust than conventional PCR and the technique has been validated with DNA extracts from different species of citrus and different tissues from diverse geographic regions ( $\mathrm{Li}$ et al 2006, 2007).

\section{Biological Indexing}

Although qPCR is currently the method of choice for diagnosis of HLB (Li et al 2006), biological indexing techniques are also available (Taba et al 2006). Due to low rate of graft transmission of the bacterium associated with HLB, the success rate for biological indexing of HLB is variable. The appropriate indicator plants are sweet orange or Orlando tangelo for African HLB and sweet orange or Ponkan mandarin for Asian HLB (Roistacher 1996). It is known that presence of the citrus tristeza virus can interfere with HLB symptom expression; and if CTV is present, grapefruit may be used as an indicator (Roistacher 1991). The preferred inoculation technique is the side graft, with leaf grafts being the alternative. The seedling indicators are trained to single leaders and held at $20-25^{\circ} \mathrm{C}$ for African HLB and $25-32^{\circ} \mathrm{C}$ for Asian HLB. Symptom expression is the typical mottle and chlorosis. The shoots are distinctly smaller, more chlorotic, and with smaller leaves than the uninoculated controls. Symptoms should appear 8 to 12 weeks after inoculation. Further details can be obtained in Roistacher $(1991,1996)$.

\section{Iodine Test}

Although the PCR test for HLB is reliable, it is considered highly expensive and labor demanding thus not suitable for indexing large numbers of samples (Etxeberria 2007). To resolve this problem, a rapid, simple field diagnostic iodine test that could be used to prescreen samples intended for PCR analysis has been developed (Taba et al 2006). Anatomical studies conducted in the 1960s, showed "massive accumulation" of starch in leaf samples from HLB infected sweet orange trees (Etxeberria et al 2009). The accumulation of starch in HLB infected leaves has been found up to six times more than healthy leaves. Since the starch readily reacts with iodine, resulting in a very dark-grey to black stain, thus this technique has been adapted as one of the easiest diagnostic tool for HLB. These diagnosis methods have been reported to be more than $90 \%$ of agreement between PCR analysis and starch tests with iodine (Etxeberria 2007). Iodine solutions products labeled as either "tincture of iodine" or "iodine tincture" in 1 to 10 with water can be used.

Takushi et al (2007) also showed scratch method for HLB detection in citrus leaves using iodine-starch reaction. They found average quantity of starch was $514.2 \mathrm{mg} / \mathrm{kg}$ in HLB infected leaves and $85.6 \mathrm{mg} / \mathrm{kg}$ in healthy leaves (Welch's $t$-test $\mathrm{p}<0.01 \%$ ), a significant difference in quantity of starch between disease and healthy leaves. Based on this result, they devised Scratch method that uses sandpaper for HLB diagnosis. Accuracy of the scratch method diagnosis in field showed more than $90 \%$ of agreement rates to PCR assay. Chamberlain and Irey (2008) compared starch-based field test for HLB to the results from real-time PCR for testing of field samples from 1759 suspected symptomatic trees. They noted that $85 \%$ of the samples were positive by RT-PCR versus $78 \%$ positive for the starch test. Therefore, they recommended that the starch test should be considered a useful tool for HLB diagnosis in the field, but not as a substitute for PCR-based testing.

\section{Spectroscopy}

In recent years, especially after detection of HLB in Brazil and Florida, USA several studies have been initiated to develop more efficient and cost-effective HLB detection techniques using spectroscopy. In a feasibility evaluation Sankaran et al (2011) found about $92 \%$ accuracy when they applied visible-near infrared spectroscopy technique for field detection of HLB in citrus trees using spectral reflectance data from the wavelength range of 350-2500 $\mathrm{nm}$.

Hawkins et al (2010) found fourier transform infrared-attenuated total reflection (FT-IR-ATR) spectroscopy as a potentially suitable and inexpensive technique for rapid and early detection of HLB. The mid-infrared region of the spectrum reveals dramatic changes that take place in the infected leaves when compared to healthy non-infected leaves. The carbohydrates that give rise to peaks in the 900$1180 \mathrm{~cm}^{-1}$ range are reliable in distinguishing leaves from infected plants versus non-infected plants. Furthermore, airborne 
multispectral and hyperspectral imaging technology has also been tested recently for rapid detection of potentially diseased trees over a large area using hyperspectral imaging software (ENVI, ITT VIS) for data analysis with 87\% accuracy (Kumar et al 2012).

Manjunath et al (2015) tested a unit Smart-DART ${ }^{\mathrm{TM}}$ connected to an Android device to detect Liberibacter in psyllids which is portable, affordable, sensitive and rapid to test. According to them with this device Psyllids can be tested to assess the prevalence of Liberibacter asiaticus in a population and for early detection of HLB in new areas being invaded by the psyllid.

In Barazil, Jarbas Caiado de Castro Neto, and his research team, spent one and a half years developing an inexpensive and portable way to detect citrus greening before the trees exhibit visible symptoms (Freshplaza, 2014). As mentioned in this report the end product is about the size of a credit card scanning machine, contains a laser, a spectrometer, and a processor to analyze the results. The principle behind this technique is that the diseased and healthy orange tree leaves emit different fluorescence spectra. Leaves affected by HLB emit more light in the middle of the visible spectrum, but have a lower peak - around $750 \mathrm{~nm}$ associated with the degradation of chlorophyll in the leaves. The spectrographic signature of citrus greening disease also appears almost immediately after a tree is infected, compared to the year or more it takes for visible symptoms to develop and this portable spectroscopic system called Agricultural Optronics Systems (AgriOS), is reported to detect citrus greening with greater than 95\% accuracy (Freshplaza 2014).

\section{ECONOMIC LOSS}

It is well known that HLB is one of the most serious citrus diseases worldwide, because once a tree is infected there is no cure and its yield is greatly reduced while the disease spreads rapidly. When, HLB becomes endemic, the disease progresses throughout the tree canopy and in the orchard very fast thereby reduce the economic life of affected orchards (Bove 2014). In many countries where HLB is present, it becomes a limiting factor for citrus production. It has been difficult to convince citrus farmers and regulatory agencies to take part in HLB management programs, because HLB management is based on elimination of diseased trees and reduction of vector population demands continuous efforts which is a costly undertaking (Bassanezi and Bassanezi 2008). Economic losses caused by HLB have been estimated in many countries and literatures on the importance and impact of the disease are available. Models that describe the disease incidence progress, disease severity progress and disease severity-fruit yield relationship according to the age of trees are also developed (Stuchi et al 2011, Roistacher 1996). In younger trees, the disease incidence and severity progress is faster than in older ones (Lopes et al 2011). Bassanezi et al (2011) have developed a mathematical model to describe HLB severity and yield relationship. According to this model HLB severity $(x)$ of a grove allows prediction of the expected yield $(y)$ using the formula: $y=\exp (-1.8 x)$, $r$ $=0.33$.

Since the 1960s, Thailand has been plagued with HLB and has had a large impact on Thailand's citrus production. Under the presence of HLB, at the end of 8 years, a farmer would be losing \$1,482 per acre, whereas if the grove was able to survive to year 10 , a profit of approximately $\$ 1,370$ per acre could be realized (Roistacher 1996). According to him in Thailand, profit is not realized unless trees survive to reach 10 years, as it takes time to recover the costs of planting and caring for the tree until production revenue is high enough to cover costs. The key problem was that in some regions of the country, groves were only lasting 6 to 8 years leading to 10 to $15 \%$ tangerine trees destruction each year. Indonesia was severely affected by HLB between 1960 and 1970 with an estimated loss of 3 million adult trees and much higher number of younger nursery plants (Gottwald et al 2007). By early 1960's the Philippines citrus plantation were estimated to cover 25,000 hectares. Ten years later 5 million trees were affected by HLB and the area planted to citrus was reduced to $60 \%$ (Aubert 1992).

The economic impact of HLB in Florida has also been assessed. HLB was first detected in Florida in 2005 and by 2014 this disease has caused significant economic and production losses costing additional US\$ 750/acre for HLB management (FreshPlaza 2014). Hodges and Spreen (2012) estimated that a reduction of 23\% in orange production during 2006 and 2010 was attributed to the presence of HLB. As a consequence, Florida's economy suffered a $\$ 3.9$ billion loss resulting to total output, total value added and labor income decrease.

In Paraguay, HLB was first detected in March 2013. To prevent the spread of disease about 600,000 adult citrus plants and approximately 2,500,000 citrus saplings belonging to some 320 nursery owners were destroyed within two years in Paraguay costing about one million US\$ to government as compensation to farmers for destroyed trees (FreshPlaza 2014a).

Quality of fruit juice is also affected by HLB. Goodrich-Schneider et al. (2008) analysed sweet orange juice hedonically for overall acceptability of flavor and sweetness among consumer panels $(n=100)$. The juice from greening-affected fruit was always significantly less acceptable $(P<0.05)$ than juice from healthy (control) fruits. Juice from greening-affected fruit was rated as significantly less sweet and significantly lower in orange flavor than juice from control fruit for all panels $(P<0.05)$. Juice expressed from visually normal fruit from HLB affected trees generally fell between control juice and greening-affected fruit juice in terms of overall acceptability, sweetness and orange flavor.

\section{HOST RANGE}

Huanglongbing is a disease of rutaceous plants (Bove 2014). None of the citrus fruit species are resistant to HLB (Bove 2006). However, responses of citrus species to 'Ca. L. asiaticus' has been found variable. It severely affects sweet orange, mandarin and tangelo trees but many other species show more or less pronounced symptoms of the disease. Mexican lime (Citrus aurantifolia) is less susceptible than sweet orange and mandarin even though it is a preferred host of the vector Diaphorina citri (Roastcher 1996). Based on severity of HLB symptoms and the ability to continue growth of the plants inoculation with ' $\mathrm{Ca}$. L. asiaticus' Folimonova et al (2009) grouped citrus genotypes into four categories as (i) sensitive: C. halimii, Nules clementine mandarin, Minneola tangelo, sweet oranges and grapefruit (ii) moderately tolerant: Sun Chu Sha mandarin, sour orange, volkamer lemon, C. macrophylla, wingle citrumelo, citron, Palestine sweet lime, acid lime, calamondin, and C. micrantha (iii) tolerant: Eureka lemon, Persian lime, Carrizo citrange, and Severinia buxifolia (iv) variable (some branch sensitive and some branch tolerant): pummelos, C. amblycarpa, cleopatra mandarin, C. indica, and 
meiwa kumquat. Ahmad et al. (2011) also classified citrus species into very susceptible, susceptible and tolerant categories based on reaction with HLB pathogen.

\section{MANAGEMENT STRATEGIES}

\section{Inoculum Reduction and Vector Control}

Currently, there is no established cure for this century-old emerging disease. There is general consensus throughout the world on three general management practices for the management of the disease; the planting of certified clean planting materials, effective control of its vector psyllid populations and removal of infected trees that serve as an inoculums source for psyllid acquisition (Bove 2006). These management practices must be adopted in order to have a successful citrus greening management program (Stuchi et al 2011). However, HLB management is difficult, if inoculum sources are widespread and the psyllid vector is well established.

There are no HLB tolerant commercial citrus species and cultivars at present to replace declining healthy trees (Bove 2006). The general control strategy has been to eradicate all existing sources of HLB within an area, then replant with HLB-free trees grown from clean budwood. Psyllid populations must also be reduced as much as possible. Biological control of the psyllid vector is only possible in locations that do not favour build-up of psyllid populations and is often compromised when hyper-parasites are present.

Preventing HLB from entering to healthy area is much easier than trying to eradicate or control it. It is important to avoid bringing propagation materials from HLB-infected areas to non infected area (Abdullah 2009). Zhang et al. (2011) has described various situations on which removal of infected trees and replanting is feasible. One strategy is to immediately reset trees that were removed. However, since psyllids are attracted to new growth and young trees flush more frequently than immature trees, young trees in a block with mature trees supporting psyllids are at greater risk than solid set young trees in a newly-planted block. Pruning may also be an extremely hazardous practice in areas under high HLB pressure, if a careful vector control program is not applied (Stuchi et al 2011) because pruning enhance new flush growth which harbor psyllids. Another strategy is to continue to remove infected trees until reduced tree numbers make the block economically unproductive, then the remove remaining trees and the entire block is replanted (Zhang et al., 2011).

Stuchi and Girardi (2011) have given detail information on various factors associated with the success or failure of HLB management based on inoculum reduction and control of psyllid vector populations by insecticide treatments adopted in Brazil. According to them HLB management practices adopted in Brazil are (i) selection of naturally occurring tolerant materials (ii) new regions for citrus production (iii) screen-house nursery trees production (iv) use of repellent and attractive plants for vector (v) protected cultivation (vi) intercropping and ultra high density (UHD) plantings (vii) intensive production systems (viii) the use of larger nursery trees.

\section{Chemical Control}

Zhang et al (2011) reported that the combination of penicillin and streptomycin (PS) was effective in eliminating or suppressing the Las bacterium and provided a therapeutically effective level of control for a much longer period of time than when administering either antibiotic separately using a propagation test system with Las-infected periwinkle and citrus plants. However, Bove (2006) suggested that antibiotic treatment has only short term effect and therefore, is not a sustainable approach in HLB control.

\section{Nutrition}

The use of nutritional applications to control or offset the deleterious effects of HLB has been a topic of considerable discussion and debate (Spann et al 2011). However, most reports are anecdotal and without sufficient statistical validity. To develop empirical evidences Gottwald et al (2011) compared combinations of nutritional components consisted of phosphite with Mn-carbonate, Mnmetalosate, Cu-metalosate, or Zn-metalosate, and injection treatments using soluble copper or silver mixed with a polymer along with a control consisting of a standard insecticide program for psyllids. There was no significant difference in titer dynamics, yield (number fruit per tree, kg fruit/tree, proportion of fruit dropped), or quality (Brix, acid, brix:acid ratio), compared to the control. The additional nutrition did not sustain tree health, yield, or fruit quality. Rather, there is a major concern that nutritional supplements may promote area-wide inoculums buildup and spread (Gottwald et al 2011).

Practice of adding additional nutrition, especially the micronutrients expecting extended productive life of infected trees has been a common practice in China (Spann et al 2011). But review of 60+ years' history of research and field practice in China reveals no consistent evidence to support the notion that nutrient management can maintain productivity of HLB-infested trees over the long term (Xia and Sequeira, 2011). Relationship of plant nutrition and HLB infection has been studied in four commercial citrus groves in Florida (Spann et al 2011). Preliminary results of the research showed that HLB-infected trees are consistently deficient in Ca, Mg, Mn, Zn and $\mathrm{B}$, and in an orchard, these nutrient deficient trees are more likely to be HLB-infected than the nutrient sufficient trees. The researchers are not yet clear whether these deficiencies were a result of decreased nutrient uptake, or if the nutrients were being bound within the plant making them unavailable. HLB-affected trees characteristically suffer from a damaged root system and nutritional disorder because of interrupted transport of photo-assimilates from shoot to the root, and mineral nutrients/water from root to the shoot (Spann et al 2011).

He et al (2011) conducted greenhouse experiments to examine the effects of growth-priming agents including root growth enhancer, trace element combination $(\mathrm{Zn}, \mathrm{Cu}$, and $\mathrm{Mn}$ ), plant growth regulators, and sugar transporter alone or in combination on HLB-affected citrus seedlings. When applied alone, root growth enhancer was most effective in promoting plant growth followed by trace element combination as indicated by a significant increase in shoot and root biomass, particularly root length and surface area, as compared with the control (He et al 2011). The main cause of visible HLB symptoms, yield reduction, and tree decline appears to be disruption of phloem tissue, which blocks the flow of photosynthate and nutrients from source to sink tissue (Bove 2006). If supplemental nutrition is 
a sustainable approach, it is expected that foliar nutrients will reduce or eliminate damage and plugging in citrus phloem tissue caused by the bacterium and possibly reduce spread or replication of the bacterium in infected trees (He et al 2011).

\section{Use of Tolerant Rootstocks}

In Barazil, 12 rootstocks namely two Rangpur limes (FCAV and Limeira), three trifoliate oranges [Rubidoux, FCAV, and Flying Dragon (FD)], Swingle citrumelo, Sunki, and Sun Chu Sha Kat mandarins, Orlando tangelo, Carrizo citrange, and the hybrids Changsha $\times$ English Small and Rangpur lime $\times$ Swingle citrumelo have been tested for HLB reaction (Stuchi et al, 2011). After a first 7year evaluation cycle for HLB infection the average cumulative incidence (CI) of HLB was $72.1 \%$, with CI values varying from 10 to $100 \%$. For most of the rootstocks, CI values were equal or higher than $60 \%$, while the trees budded onto the FD rootstock showed the lower HLB incidence (10\%). Albrecht and Bowman (2012) used greenhouse inoculation tests and field trials to investigate the tolerance of some Citrus $\times$ Poncirus hybrids to infection of Candidatus Liberibacter asiaticus (Las). The citrus rootstock US-897 (Citrus reticulata Blanco $\times$ Poncirus trifoliata L. Raf.) was observed to be tolerant to HLB in field plantings (Albrecht and Bowman 2012).

\section{Guava Intercropping}

Since long, famers from Mekong Delta of South Vietnam have been practicing interplanting of citrus with guava and those citrus orchards planted with guava showed much lower psyllid infestation levels and low incidence of HLB compared to citrus orchards lacking guava (Hall et al 2007). This practice adopted by Vietnamese farmers drew the attention of scientific communities of many countries during 1990s and various scientific studies were initiated to understand the scientific reasons. The first of this kind of research was a collaborative research projects involving Vietnamese, Japanese and Australian scientists (Beattie et al 2006). The findings of this research which was presented in a meeting held during December 2006 in Japanese International Research Center showed that interplanting citrus with guava negated infestations of Asian citrus psyllid and consequently HLB (Beattie et al 2006). This study collected the scientific information that young citrus interplanted with guava remained disease-free for a year whereas sole citrus crop showed signs of the disease within four months of planting and reached over 30\% trees infected within a year (Hall et al 2007).

A team of American scientists who also made a observation tour to Vietnam in April 2000 noted that the normal life of sole citrus plantings in Mekon region of Vietnam was 2 to 4 years, but those interplanted with white guava were surviving for up to 15 years (Gottwald et al 2010). Although raising guava as an intercrop reduced psyllid population in citrus orchards (Hall et al 2007), the mechanism by which this occurs was unknown. It was postulated that the effects of guava on citrus psylla could be due to mechanical/physical disruption on host recognition, repellent effect of volatile compounds from guava or chemical alteration of the volatile compounds emitted by citrus reacting with guava compounds. From various studies conducted in Florida, USA to determine, if guava has a repellent effect on adults of Asiatic citrus psyllids. Gottwald et al. (2010) noted high adult mortality rates occurred when psyllids were confined to guava in no-choice situations, with 95\% mortality occurring within 6-9 days. They postulated that the effect may be due to volatile compounds produced by guava that are deleterious to psyllids. In another study, Zaka et al (2010) evaluated the repellent effect of guava leaf and factors attributed to this activity, response of adult psyllids to guava leaves and its odor in cage test and Y-tube alfactometer test. The alfactometer response of adult psyllids to guava leaf odor was dose-dependent and both male and female psyllids responded similarly to the guava leaf odor.

Since more than $75 \%$ of the Florida citrus crops has been infected with HLB, USDA has provided 43 million US \$ for its research (FreshPlaza 2015b). Funded projects include a grant to the University of Florida to develop a bactericide that can be applied to infected citrus trees to reduce or eliminate pathogens, a project at Kansas State University to develop a therapeutic delivery system that will prevent Candidatus Liberibacter asiaticus from infecting plants or prevent the development of HLB in infected citrus, and a grant at the University of California-Davis that focuses on using new genetic approaches to managing the Asian citrus psyllid that causes HLB (FreshPlaza 2015b).

\section{CONCLUSION}

Review of scientific literatures revealed that HLB is the most devastating disease of citrus fruit crops. Most commercial citrus species of Nepal like mandarin and sweet orange are very susceptible to the disease while acid lime is slightly tolerant, but it is carrier of HLB bacterium serving as hidden source of innoculum. The disease is present in Nepal since early 1960s and has spread many commercial citrus pockets of the country over the years (Bove, 2006 \& 2014, Regmi et al, 1996 \& 2010, Regmi and Yadav, 2007). Past research efforts were found mainly focused on survey and disease indexing leaving inadequate attention to its long term management. It has resulted to massive decline of citrus orchards especially located below $1000 \mathrm{~m}$ altitude where population of vector - psyllid is abundant. Therefore, successful HLB management strategies particularly those of Brazil and Florida can be adopted in Nepal to save country's citriculture.

\section{ACKNOWLEDGEMENTS}

Partial fund for the present study was supported by Nepal Agricultural Research Council. Thanks to an anonymous reviewer for fruitful critics and suggestion on the paper. 


\section{REFERENCES}

Abdullah TL, HS Shokrollah, S Kamaruzaman and SA Abdullah. 2009. Control of Huanglongbing (HLB) disease with reference to its occurrence in Malaysia. African Journal of Biotechnology 8:4007-4015.

Ahmad K, K Sijam, H Hashim, A Abdu and Z Rosli. 2011. Assessment of Citrus Susceptibility towards Candidatus Liberibacter Asiaticus-Terengganu Isolate Based on Vector and Graft Transmission Tests. Journal of Agricultural Science 3:159-166.

Albrecht U and KD Bowman. 2012. Tolerance of trifoliate citrus hybrids to Candidatus Liberibacter asiaticus. Scientia Horticulturae 147:71-80.

APTN. 2013. Applied Nanotech Receives Contract from California Citrus Research Board. Accessed on 6 January 2015 from http://www.appliednanotech.net/news/pdf/2013-02-04.pdf.

Aubert A. 1992. Citrus greening disease a serious limiting factor for citriculture in Asia and Africa. Proc. Int. Soc. Citriculture. 2:817-820.

Bassanezi RB and RC Bassanezi. 2008. An approach to model the impact of Huanglongbing on citrus yield. In: Proceedings of the International Research Conference on Huanglongbing (TR Gottwald and JH Graham, eds), 1-4 Dec 2008, Florida, USA. Pp.301.

Bassanezi RB, LH Montesino, L Amorim, MCG Gasparoto, AB Filho and L Amorim. 2011. Yield reduction caused by Huanglongbing in different sweet orange cultivars in São Paulo, Brazil. European Journal of Plant Pathology. 130 (4): 577-586.

Bassanezi RB, LH Montesino, L Amorim., MCG Gasparoto., FA Bergamin. 2008. Yield reduction caused by Huanglongbing in different sweet orange cultivars in São Paulo, Brazil. In: Proceedings of the International Research Conference on Huanglongbing (TR Gottwald and JH Graham eds), 1-5 Dec. 2008, Orlando, Florida, USA. Pp 270.

Batool A, Y Iftikhar, SM Mughal, MM Khan, M J Jaskani, M Abbas, IA Khan. 2007. Citrus Greening Disease - A major cause of citrus decline in the world - A Review. Hort. Sci. (Prague) 347 (4): 159-166.

Beattie GAC, DJ Mabberley, P Holford, P Broadbent, P De Barro. 2005. Huanglongbing: its possible origins, collaborative research in Southeast Asia, and developing incursion management plans for Australia. In: Proceedings of 2nd International Citrus Canker and Huanglongbing Research Workshop, (TR Gottwald, WN. Dixon, JH Graham, P Berger eds.), November 7-11, 2005, Orlando, Florida. Pp 52.

Beattie GAC, P Holford P, DJ Mabberley, AM Haigh and P Broadbent. 2008. On the Origins of Citrus, Huanglongbing, Diaphorina citri and Trioza erytreae. In: Proceedings of the International Research Conference on Huanglongbing (TR Gottwald and JH Graham eds), 1-4 Dec 2008, Orlando, Florida, USA. Pp 23-54.

Beattie GAC, P Holford, DJ Mabberley, AM Haigh, R Bayer and P Broadbent. 2006. Aspects and insights of Australia-Asia collaborative research on huanglongbing. In: Proc. Intl. Workshop for Prevention of Citrus Greening Diseases in Severely Infested Areas, 7-9 December 2006, Ishigaki, Japan. Japanese Ministry of Agriculture, Forestry and Fisheries, Japan. Pp. 47-64

Belasque J, RB Bassanezi, PT Yamamoto, SA Lopes, AJ Ayres, A Tachibana, AR Violante, A Tank Jr, CL Giorgetti, FD Giorgi, GM Menezes, J Dragone, LF Catapani, RH Jank Jr. 2008. Factors associated with control of huanglongbing in San Paulo, Brazil: a case study. In: Proceedings of the International Research Conference on Huanglongbing (TR Gottwald and JH Graham eds), 15 Dec. 2008, Orlando, Florida, USA. Pp 337.

Bové JM. 2014. Huanglongbing or yellow shoot, a disease of Gondwanan origin: Will it destroy citrus worldwide? Phytoparasitica. 42:579-583

Bové, J.M. 2006. Huanglongbing: A destructive, newly-emerging, century-old disease of citrus. J. Plant Pathol. 88:7-37.

Capoor SP, DG Rao and SM Viswanath. 1967. Diaphorina citri Kuwary - a vector of the greening disease of citrus in India. Ind. J. Agric. Sc. 37: 572-576.

Chamberlain HL, and MS Irey. 2008. Comparison of a starch-based field test for Huanglongbing to results from real-time PCR testing of field samples from symptomatic trees in Florida. In: Proceedings of the International Research Conference on Huanglongbing (TR Gottwald and JH Graham eds.), 1-5 Dec. 2008, Orlando, Florida, USA. Pp 114.

Das AK, S Nerkar, S Bawage, A Kumar. 2014. Current distribution of huanglongbing (citrus greening disease) in India as diagnosed by real-time PCR. Journal of Phytopathology. 162(6): 402-406.

Das AK. 2008. Citrus greening (Huanglongbing) disease in India: Present Status and Diagnostic Efforts. In: Proceedings of the International Research Conference on Huanglongbing (TR Gottwald and JH Graham eds.), 1-5 Dec. 2008, Florida, USA. Pp.129.

Etxeberria E P, D Gonzalez, W Dawson and T Spann. 2007. Iodine based starch test to assist in selecting leaves for HLB. In: Citrus Notes, Vol. 07-08. University of Florida, USA.

Etxeberria, EP, D Gonzalez, D Achor, G Albrigo. 2009. Anatomical distribution of abnormally high levels of starch in HLB-affected valencia orange trees. Physiological and Molecular Plant Pathology. 74(1):76-83

Folimonova SY, CJ Robertson, SM Garnsey, S Gowda and WO Dawson. 2009. Examination of the responses of different genotypes of citrus to huanglongbing (citrus greening) under different conditions. Phytopathology 99:1346-1354.

FreshPlaza, 2014a. Paraguay: Removal of plants generates crisis for citrus producers. In: Global Fresh Produce and Banana News. Assessed in 7 Jan 2015 from http://www.freshplaza.com/article/119515/.

FreshPlaza, 2015b. USDA approves \$23 million for citrus greening research. In: Global Fresh Produce and Banana News. Assessed in 3 April, 2015 from http://www.freshplaza.com/ article/137790/USDA.

FreshPlaza. 2014b. Portable Hanglongbing (greening disease) detector. In: Global Fresh Produce and Banana News Assessed in 7 Jan. 2015 from http://www.freshplaza.com/ article/128529/Brazil-Portable-detection-for-citrus-greening.

FreshPlaza. 2015a. Bitter times on Florida Citrus. In: Global Fresh Produce and Banana News. Assessed in 6 March 2015 from http://www.freshplaza.com/article/136078/Bitter-times-for- Florida-Citrus

Garnier M, and JM Bove. 1977. Structure trilamellaire des deux membrenes qui entourent les organismes prokaryotes assoc'ies a la maladie du "greening" des agrumes. Fruits 32:749-752.

Garnier M, J Eveillard, S Cronje, CPR Le, HF Roux and JM Bové. 2000. Genomic characterization of a liberibacter present in an ornamental rutaceous tree, Calodendron capense in the Western Cape province of South Africa. Intl. J. Syst. Evol. Microbiol.50: 2119 - 2125. 
Garnier M, N Danel and J M.Bové. 1984. Etiology of citrus greening disease. Ann. Microbiol. 135A:169 -179.

Goodrich-Schneider R, CA Sims, T Span, MD Danyluk and RL Rouseff. 2008. Effect of greening plant disease (Huanglongbing) on orange juice flavor and consumer acceptability. In: Proceedings of the International Research Conference on Huanglongbing (TR Gottwald and JH Graham eds), 1-5 Dec. 2008, Orlando, Florida, USA. Pp.269.

Gottwald TR, DG Hall, GAC Beattie, K Ichinose, MC Nguyen, M Bar-Joseph, S Lapointe, E Stover, PE. Parker, G McCollum, QD Le and ME Hilf. 2010. Investigations of the effect of guava as a possible tool in the control/management of huanglongbing. In: Insect-Transmitted Procaryote. Proceedings of the $17^{\text {th }}$ Conference of IOCV, Adana, Turkey (ME Hilf, LW Timmer, RG Milne and JV da Graça eds). Accessed in 26 Jan. 2015 from http://www.ivia.es/iocv/

Gottwald TR, JV da Graca and RB Bassanezi. 2007. Citrus Huanglongbing: The pathogen and its impact. Plant Health Progress, 6 September 2007. Accessed in 9 January 2014 from http://www.plantmanagementnet work. org/pub/php/ review/2007/huanglongbing/

Gottwald TR, MS Irey, JH Graham, B Wood. 2011. Nutritional treatments: Inconsequential effect on HLB: control and promote areawide titer increase and disease spread. In: Proceedings of $2^{\text {nd }}$ International Research Conference on Huanglongbing (JK Burrns, JH Graham and TR Gottawald eds), Jan. 10-15, 2011, University of Florida, USA. Pp 178

Grosser JW, M Dutt, A Shohael, GA Barth. 2011. Progress using transgenic approaches and biotechnology-facilitated conventional breeding to develop genetic resistance/tolerance to HLB in commercial citrus. In: Proc. $2^{\text {nd }}$ International Research Conference on Huanglongbing (JK Burrns, JH Graham and TR Gottawald eds), Jan. 10-15, 2011, University of Florida, USA. Pp.198

Hall DG, TR Gottwald, CM Nguyen, K Ichinose, DQ Le, A Beattie. 2007. Intercropping of citrus and guava trees for management of Huanglongbing. Florida Entomological Society Annual Meeting, July 15-18, 2007, Sarasota, Florida. Accessed in 24 March 2015 from http://www.ars.usda.gov/research/publications/publications.htm?seq_no_115=212117

Hall DG, TR Gottwald, N M Chau, K Ichinose, LQ Dien and GAC Beattie. 2007. Intercropping of citrus and guava for management of Huanglongbing. Assessed on 5 Jan. 2015 from www.itfnet.org/fruit/Slides/Session\%204/FES_Guava_Presentation_2007_v3\%5B1\%5D.pdf.

Hawkins SA, B Park, GH Poole, T Gottwald, WR Windham and KC Lawrence. 2010. Detection of Citrus Huanglongbing by Fourier Transform Infrared-Attenuated Total Reflection Spectroscopy. Applied Spectroscopy 64 (1): 100-103

He Z, MQ, Zhang, E Viana, T Merlin, YP Duan, PJ Stoffella, CA Powell. 2011. Use of growth-priming agents to extend the growth of HLB-affected citrus. In: Proceedings of $2^{\text {nd }}$ International Research Conference on Huanglongbing (JK Burrns, JH Graham and TR Gottawald eds), Jan. 10-15, 2011, University of Florida, USA. Pp 186.

Hodges AW and TH Spreen. 2012. Economic impacts of citrus greening (HLB) in Florida, 2006/07-2010/11. Gainsville, Florida: Food and Resource Economics Department, Florida Cooperative Extension Service, Publication FE903, 2012.

Jagoueix S, JM Bové and M Garnier. 1996. PCR detection of the two 'Candidatus' Liberobacter species associated with greening disease of citrus. Mol. Cell. Probes. 10: 43-50.

Johnson EG, MS Irey, T Gast, DB Bright and JH Graham. 2011. Evaluation of foliar zinc and manganese for control of HLB or associated symptom development. In: Proceedings of $2^{\text {nd }}$ International Research Conference on Huanglongbing (JK Burrns, JH Graham and TR Gottawald eds), Jan. 10-15, 2011, University of Florida, USA. p.187.

Johnson EG, J Wu, DB Bright, JH Graham, 2014. Association of 'Candidatus Liberibacter asiaticus' root infection but not phloem plugging with root loss on huanglongbing-affected trees prior to appearance of foliar symptoms. Plant Pathology. 63 (2): 290

Knorr LC, SM Sah and OP Gupta. 1970. Greening disease of citrus in Nepal. Plant Disease Reporter. 54: 1092-1095

Kumar A, WS Lee, RJ Ehsani, LG Albrigo, C Yang and RL Mangan. 2012. Citrus greening disease detection using aerial hyperspectral and multispectral imaging techniques. J. Appl. Remote Sens. 6(1):23-35. Accessed on 2 March 2015 from http://remotesensing.spiedigitallibrary.org/article. aspx?articleid=1352380http://dx.doi.org/10.1117/ 1.JRS.6.063542.

Li WB, JS Hartung and L Levy. 2006. Quantitative real-time PCR for detection and identification of Candidatus Liberibacter sp. associated with citrus huanglongbing. J. Microbiol. Methods. 66:104-115.

Li WB, JS Hartung and L Levy. 2007. Evaluation of DNA amplification methods for improved detection of "Candidatus Liberibacter species” associated with citrus huanglongbing. Plant Disease 91:51-58.

Lopes SA, RB Bassanezi, J Belasque Jr. and PT Yamamoto. 2011. Management of citrus Huanglongbing in the state of Sao Paulo, Brazil. Accessed on 25 Feb. 2015 from http://www.agnet. org/ htmlarea_file/library/ 20110712174730/eb609.pdf

Manjunath LK, C Ramadugu, E Rodriguez, R Kubota, S Shibata, DG. Hall, ML Roose, D Jenkins and RF Lee. 2015. A rapid field detection system for citrus huanglongbing associated 'Candidatus Liberibacter asiaticus' from the psyllid vector,Diaphorina citri Kuwayama and its implications in disease management. Crop Protection. 68:41-4

MoAD, 2013. Statistical Information on Nepalese Agriculture 2012/2013. Ministry of Agriculture Development, Agri-Business Promotion and Statistical Division, Singh Durbar, Kathmandu, Nepal.

NAPPO. 2012. Diagnostic Protocols: DP 02 Citrus Huanglongbing. Secretariat of the North American Plant Protection Organization (NAPPO), Ottawa, Ontario, Canada. Accessed on 24 Jan 2015 from http://www.aphis.usda.gov/import_export/plants/plant_exports/downloads/NAPPO_HLB_DP_2_2012-05-30-e.pdf

Oberholzer PCJ, DFA von Standen, WJ Basson. 1965. Greening disease of sweet orange in South Africa. In: Proceedings of 3rd Conference of International Organization of Citrus Virologist (IOCV), (NC Price ed.), 16-25 Sept. 1963, Brazil. Pp $213-219$.

Regmi C and BP Yadav. 2007. Present status of Huanglongbing in western districts of Nepal. Proc. $4^{\text {th }}$ Hort. Seminar, Jan 18-19, 2007, Kirtipur, Kathmandu, Nepal, Nepal Hrticulture Society. Pp 40-43.

Regmi C and TK Lama. 1988. Greening incidence and greening vector population dynamics in Pokhara. Proc. $10^{\text {th }}$ Conference of International Organization of Citrus Virologist (IOCV), (LW Timmer, SM Garnsey and L Navarro eds.), 12-21 Nov. 1986, Valencia Spain. Pp.238-242. 
Regmi C, M Garnier and JM Bove. 1996. Detection of the Asian Huanglongbing (Greening) Liberobacter in Nepal by DNA DNA Hybridization in Nepal. Proceedings of the Thirteenth IOCV Conference - Procaryotes and Blight. 16-23 November, 1996, Fujian, China.1996, Pp 2067-270.

Regmi C. 1982. Mycoplasma-like disease of citrus in Nepal and USSR. Ph. D. Dissertation. Moscow Agriculture Academy, USSR.

Regmi C.1994. Detection of greening disease by DNA probes. Proceedings of $2^{\text {nd }}$ National Conference of Science and Technology. 8-11 June, 1994, Royal Nepal Academy of Science and Technology, Khumaltar, Kathmandu. Pp 394-398.

Regmi C, RP Devekota, KP Paudyal, S Shrestha, AJ Ayers, N Murcia, JM Bove and N Duran Vila. 2010. Shifting from seedling mandarin trees to grafted trees and controlling huanglongbing and viroids: a biotechnological revolution in Nepal. In: InsectTransmitted Procaryote. Proceedings of the $17^{\text {th }}$ Conference of IOCV, Adana, Turkey (ME Hilf, LW Timmer, RG Milne and JV da Graça eds). Accessed in 26 Jan. 2015 from http://www.ivia.es/iocv/

Reinking OA. 1919. Diseases of economic plants in southern China. Philippine Agricultural. 8: 109-135.

Roistacher CN. 1996. The economics of living with citrus diseases: Huanglongbing (Greening) in Thailand. In: Proceedings of the Thirteenth IOCV Conference - Procaryotes and Blight (JV da Graca, P Moreno, RK Yokimi eds). 16-23 November, 1996, Fujian, China. Pp. 279-285.

Salibe AA, RE Cortez, 1968. Leaf mottling, a serious virus disease of citrus in the Philippines. In: Proceedings of 4th IOCV Conference (JFL Childs ed.). 2-12 October, 1966, Italy. University Florida Press, Gainesville. Pp 131-136.

Sankaran S, A Mishra, JM Maja, R Ehsani. 2011. Visible-near infrared spectroscopy for detection of Huanglongbing in citrus orchards. Computers and Electronics in Agriculture 77: 127-134.

Sankaran S, R Ehsani, E Etxeberria. 2010. Mid-infrared spectroscopy for detection of Huanglongbing (greening) in citrus leaves. Talanta 83: 574-581. Assessed on 10 Feb. 2015 from www.elsevier.com/locate/talanta.

Slot SB. 2014. Greening disease continues to cause low yields in Florida. Global Fresh Produce and Banana News. Accessed on 11 Jan 2015 from www.freshplaza.com.

Spann TM, RE Rouse, AW Schumann. 2011. The Theory of managing Huanglongbing with plant nutrition and real world success in Florida. In: Proceedings of $2^{\text {nd }}$ International Research Conference on Huanglongbing (JK Burrns, JH Graham and TR Gottawald eds), Jan. 10-15, 2011, University of Florida, USA. PP 177

Statista. 2012. Global fruit production in 2012 by variety. Accessed on 20 April, 2015 from http:/www.statista.com/statistics/264001/worldwide-production-of-fruit-by-variety/

Stuchi ES and EA Girardi. 2011. Use of horticultural practices in citriculture to survive Huanglongbing. In: Proceedings of $2^{\text {nd }}$ International Research Conference on Huanglongbing (JK Burrns, JH Graham and TR Gottawald eds), Jan. 10-15, 2011, University of Florida, USA. Pp 189

Stuchi ES, ET Reiff, OR Sempionato, T Cantuarias-Avilés, EA Girardi, LG Parolin and DA Toledo. 2011. Rootstocks and pruning effects on Huanglongbing incidence on Tahiti Limes in Bebedouro, Northern São Paulo State, Brazil. In: Proceedings of $2^{\text {nd }}$ International Research Conference on Huanglongbing (JK Burrns, JH Graham and TR Gottawald eds), Jan. 10-15, 2011, University of Florida, USA. Pp 204

Su HJ. 2008. Research and health management of citrus Huanglongbing in Taiwan. In: Proceedings of the International Research Conference on Huanglongbing (TR Gottwald and JH Graham eds.), 1-5 Dec. 2008, Orlando, Florida, USA. Pp 57.

Taba S, K Nasu, K Takaesu, A Ooshiro and Z Moromizato. 2006. Detection of citrus huanglongbing using an iodo-starch reaction. The Science Bulletin of the Faculty of Agriculture, University of the Ryukyus. 53:19-24.

Takushi T, T Toyozato, S Kawano, K Taba, A Ooshiro, M Numazawa and M Tokeshi. 2007. Scratch method for simple, rapid diagnosis of citrus huanglongbing using iodine to detect high accumulation of starch in citrus leaves. Japanese Journal of Phytopathology. 73: 3-8.

Teixeira DC, C Saillard, S Jagoueix-Eveillard, JL Danet, AJ Ayres, and JM Bové. 2005. "Candidatus Liberibacter americanus" associated with citrus huanglongbing (greening disease) in São Paulo State, Brazi l. Intl. J. Syst. Evol. Microbiol. 55:1857-1862.

Thrower, L. B. 1968. Report on visit to Nepal. FAO Report PL: T51

UNCTAD. 2011. Citrus Fruit Market. Assessed on 21 April 2015 from http://www.unctad.info/en/ Infocomm/Agricultural_Products/Citrus-fruit/market/

Xia Y, R Sequeira. 2011. Nutritional approaches for management of Huanglongbing (citrus greening) in China. In: Proceedings of $2^{\text {nd }}$ International Research Conference on Huanglongbing (JK Burrns, JH Graham and TR Gottawald eds), Jan 10-15, 2011, University of Florida, USA. p.179

Zaka S, M Xin-Nian Zeng, H Paul, G Andrew and C. Beattie. 2010. Repellent effect of guava leaf volatiles on settlement of adults of citrus psylla, Diaphorina citri Kuwayama on citrus. Insect Sci.: 17(1): 39-45

Zhang MQ, CA Powell, LJ Zhou, Z He, E Stover and YP Duan. 2011. Chemical compounds effective against the citrus Huanglongbing bacterium, Candidatus Liberibacter asiaticus. In: Proceedings of $2^{\text {nd }}$ International Research Conference on Huanglongbing (JK Burrns, JH Graham and TR Gottawald eds.), Jan. 10-15, 2011, University of Florida. p.175. 